\title{
Entrepreneurship, National Culture \& Firm Growth
}

\author{
Rakesh Gupta \\ Institute of Management Technology (IMT), Ghaziabad, India \\ Email:rgupta@imt.edu
}

How to cite this paper: Gupta, R. (2018) Entrepreneurship, National Culture \& Firm Growth. Theoretical Economics Letters, 8, 1401-1411.

https://doi.org/10.4236/tel.2018.87090

Received: March 20, 2018

Accepted: May 29, 2018

Published: June 1, 2018

Copyright $\odot 2018$ by author and Scientific Research Publishing Inc. This work is licensed under the Creative Commons Attribution International License (CC BY 4.0).

http://creativecommons.org/licenses/by/4.0/

\section{c) (i) Open Access}

\begin{abstract}
This study talks about the inter-linkage of strategy and entrepreneurship and the emergence of strategic entrepreneurship concept. It explores the overlap between strategy, entrepreneurship and the nature of entrepreneurial strategy making construct (EO). The key purpose of this research is to study the EO construct, which takes into consideration both the strategic and entrepreneurial behavior of the firm and the key dimensions comprising this construct. Lumpkin and Dess's conceptualized entrepreneurial orientation (EO) construct as comprising of five dimensions, innovativeness, risk-taking, pro-activeness, competitive aggressiveness and autonomy, which vary independently. The study proposes a model linking cultural dimensions and strategic entrepreneurship (EO) and its influence on firm growth. The study puts forward an argument that those countries which display certain cultural aspects will have a strong EO, hence contributing to firm growth.
\end{abstract}

\section{Keywords}

Entrepreneurship, Strategy, Entrepreneurial Orientation (EO), National Culture \& Firm Growth

\section{Introduction}

The origin of term entrepreneurship can be traced to the French word "Entreprendre", which is "to undertake". Though the strict definition of entrepreneurship is yet to emerge, it is widely considered as identification and exploitation of new opportunities. Wiklund [1] and Hitt et al., [2] talked about entrepreneurship as "taking advantage of opportunities by novel combination of resources in ways which have impact on the market", and entrepreneurial actions as "creating new resources or combining existing resources in new ways to develop and commercialize new products, move into new markets, and/or service new cus- 
tomers". Berger [3] mentioned that though many countries have made significant progress in developing their economies, they have achieved limited success in strengthening entrepreneurial activity. He attributed the reason behind this gap is that these countries are yet to make the fundamental cultural shift that encourages entrepreneurial behavior. As per him, it is the culture, which is the conductor, while the role of entrepreneur is to act as a catalyst to entrepreneurship. For entrepreneurship to thrive countries need to have requisite national culture that encourages entrepreneurial activity.

Researchers have stated that entrepreneurship means identifying and exploiting new opportunities by making new entry but to create value entrepreneurial firms need to act strategically. Lumpkin \& Dess [4]. McGrath \& MacMillan [5] stressed the importance of entrepreneurial mind-set for strategists to sense and exploit opportunities. Kuratko et al. [6] held that firm level entrepreneurship provides direction to the company by acting as key aspect of firm's strategy by defining where the firm is headed and how it intends to reach there. Despite this shared focus, the two disciplines of strategy \& entrepreneurship have evolved separately. Of late scholars have started calling for the need of integration of these two fields. Miller's [7] highlighted the importance of strategic decision-making of firm and stressed its relevance in judging presence/absence of entrepreneurship within a firm. He described firm's entrepreneurial behavior by its willingness to be innovative, ability to take risks and act proactively whereas non entrepreneurial firms failed to innovate, were highly risk averse, and followed competition rather than being proactive. It involves how uncertainty can be used to one's advantage by developing an entrepreneurial mind-set through taking calculated risks [5]. Covin and Miles [8] have talked about the fact that firms with entrepreneurial approach towards strategy tend to perform better than those who don't. As per them, an entrepreneurial strategy is, "a vision directed organization with reliance on entrepreneurial behavior that purposefully and continuously rejuvenates the organization and shapes scope of its strategy through recognition and exploitation of entrepreneurial opportunity". Wales et al. [9] mentioned that strategic entrepreneurship and the emergence of strategic \& entrepreneurial orientation (EO) construct have provided critical insights into questions like firm level entrepreneurial strategy and its performance implications.

The significance of this paper stems from the fact that it tries to highlight the role of national culture and its relationship with various aspects of entrepreneurship and its influence on firm growth. Since the construct of Entrepreneurial Orientation through the manifestations of its dimensions and the relevance of culture in influencing entrepreneurship have also been studied earlier. But the main contribution of this study is to highlight the specific aspects of culture and its influence on specific aspects of entrepreneurial behavior, which has not been examined in the earlier studies. At the same time, one of the limitations of this study is that though it has proposed the conceptual model but has not empiri- 
cally tested it.

This paper has been organized it in the following section; it starts with the introduction stating the issues to be studied, then explores the inter-relationship between entrepreneurship and national culture. Further it studies the EO Construct and the five dimensions comprising this construct. The study moves on to explain the independent nature of these dimensions and conclude with proposing the model to study this.

\section{Entrepreneurship \& National Culture}

Past research highlights that certain cultural dimensions encourage entrepreneurship far more and in countries with these cultural attributes entrepreneurship is far more prevalent. Hofstede's [10] highlighted that different countries vary on certain cultural aspects like power distance, avoiding uncertainty, individualism/ collectivism, and masculinity/ femininity. He further stated that there is a linkage between these dimensions, entrepreneurship and national wealth and economic growth. Building on Hofstede [10] work, Trompenaars [11] examined additional cultural aspects of need for achievement/ascription and universalism and their influence on entrepreneurship.

Using the above mentioned cultural dimensions, one can identify a culture, which is more conducive to strong strategic entrepreneurship (EO). So cultural factors have a strong influence on society's capacity to harness EO. To develop new ideas, entrepreneurs need to take decisive actions in situations, which have few parallel historical trends, and very limited information. Like starting a new venture means dealing with lot of uncertainty. Cultures, which encourage this kind of approach and action have little tolerance of power distance, open to operating in uncertainty, are more individualistic, masculine and achievement centered. While the societies that are sensitive about rigid social structure, committed to hierarchy, job security, consensual approach to decision making accept power distance, try to avoid uncertainly, be more collective, feminine and particularistic.

\section{Strategic Entrepreneurship or EO Construct}

Entrepreneurship refers to making new entry, whereas EO centers on the entrepreneurial process, which means how this is undertaken-the methods, practices, and decision-making styles used to act entrepreneurially. Miller [7] talked about an entrepreneurial organization as "one that engages in product market innovation, undertakes somewhat risky ventures, and is first to come up with "proactive" innovations, beating competitors to the punch." This laid the foundation of the entrepreneurial orientation construct with key dimensions of innovativeness, risk taking and pro-activeness. Lumpkin and Dess [4] defined EO comprising of five dimensions, and added competitive aggressiveness and autonomy to the existing three. They talked about the fact that organizations that behave independently (autonomy), are open to change, take more risks and in- 
itiatives (pro-activeness), and compete aggressively have a strong EO. Past literature argues that EO is important for the economic growth of nations Morris [12]. While some societies experience higher levels of entrepreneurship, which does depend upon host of cultural factors that combine together to foster a strong EO.

\section{Dimensions of Strategic Entrepreneurship (E0) Construct}

Strategy is all about choices and as per Child's [13] strategic choice perspective, EO has emerged as a widely researched construct in strategy and entrepreneurship area and as noted by Zahra [14], there has been substantial research undertaken in this area in last three decades. Miller [7] suggested the aspects of "innovativeness," "risk taking," and "proactiveness" to explain firm level entrepreneurship i.e. EO. The inclusion of additional two dimensions, autonomy and competitive aggressiveness to the existing three can be traced back to the work of Burgelman's [15], who talked about autonomous behavior of firms and individuals while Miller's [7] idea of "beating competitors to the punch" was captured through the dimension competitive aggressiveness. Increasingly literature on EO has talked about these five dimensions comprising this construct.

\subsection{Innovativeness}

Schumpeter [16] was the one who stressed on the role of innovation and highlighted its relevance in entrepreneurial process. He held that societal, technological, and market imperfections can be overcome through increased competition as a result of innovation. Cooper [17] stated that continuous innovation alters competitive boundaries and reduces product and process life cycles. Early definitions of innovation focused on the extent to which an organization could develop new technologies or practices which are currently not available in a market Kimberly, [18].

Miller and Friesen [19] talked about two competing models of innovation, depending on the goals and nature of organization: the conservative and the entrepreneurial one. While the conservative one talks about the innovative practices of organizations using it as a measure of defence, or as a measure of retaliation. Firms adopting this approach normally innovate in the midst of difficult environment or competitive situations in an attempt to regain their original market position. In contrast, the entrepreneurial model is practiced in firms which consistently and aggressively pursue innovative practices that will give the company a competitive edge. Drucker [20] mentioned, "Innovation is a specific tool of entrepreneurs, means by which they exploit change as an opportunity for a different business or service. It is presented as a discipline, capable of being learned and practiced".

Knight [21] defined innovation as "the pursuit of creative or novel solutions to challenges confronting the firm, including the development or enhancement of products and services, as well as new administrative techniques and technolo- 
gies for performing organizational functions." Zahra and Bogner [22] suggested innovation as an organizational asset that helps in providing wider range of strategic choices to them in their pursuit of enhanced performance. Zahra [23] defined innovation to be "creating new business through market developments or by undertaking product, process, technological and administrative innovations".

Presence or absence of innovation plays key role in entrepreneurship as people or organizations work in cultures that either encourage or inhibit experimentation to overcome the existing problems and this is the key factor, which indicates the innovativeness aspect of EO. National cultures that are more open to experimentation are more likely to experience development of new ideas in relation to other countries.

\subsection{Risk-Taking}

The influence of risk taking behavior on the actions of entrepreneurs was first proposed when the idea of entrepreneurship was originally generated. Entrepreneurial literature since the work of Cantillon [24] highlighted risk taking as a distinguishing factor between an entrepreneur and non-entrepreneur. Mill [25] suggested various entrepreneurial functions as direction, control, superintendence and risk bearing; he believed that inclusion of risk bearing distinguished "entrepreneur" from "manager." While the types of risk taken by entrepreneurs have broadened overtime, as the term entrepreneurship has come to represent more than only self-employed individuals, the risk taking behavior has continued to be a key element in distinguishing them from other individuals. McClelland [26] posited, "Practically all theorists agree that entrepreneurship involves, by definition, taking risks of some kind". The propensity of firm to take risk is an important component of entrepreneurial orientation construct as risk is an inescapable part of business.

Stinchcombe, [27], held that new firms and start-ups are compelled to take risks in comparison to large established firms to overcome obstacles to survival and growth. Covin and Slevin [28] described "risk taking with regard to investment decisions and strategic actions in face of uncertainty". Antoncic and Hisrich [29] defined risk taking as the "possibility of loss related to quickness in taking bold actions and committing resources in the pursuit of new opportunities". Societies that have a culture to support the risk-taking appetite of entrepreneurs by tolerating ambiguity and uncertainty and devote adequate resources to somewhat risky projects are likely to reap the benefits.

\subsection{Pro-Activeness}

Right from the work of Penrose [30], firms' have laid a lot of emphasis on taking initiative to capture new opportunities. Miller and Friesen [19] referred to pro-activeness of a firm's decisions is determined by answering the question, "does it shape the environment by introducing new products, technologies, ad- 
ministrative techniques, or does it merely react?" Lieberman \& Montgomery [31] acknowledged the advantage of making a first move, often labeling this as the key criterion of pro-activeness. Naman and Slevin [32] suggested examination of the number of first mover projects in an organization. Miller and Camp [33] investigated the benefits of being a first mover relative to other organizations who quickly followed into a newly established market and argued that organizations could still be characterized as novel, fast, and forward thinking without being the first mover. Further, they found that the first and second firms to enter a market are considered to be equally pioneering and had an equal likelihood of success in the new market. Thus, while being the first mover has great advantages, these can still be captured by another organization that quickly follows the first mover in the market. So being first might not be of utmost importance but quick market entry and/or quick response to the actions of industry competitors is vital to organizational success.

Penrose [30] emphasized pro-activeness provides the direction and imagination necessary to engage in opportunistic expansion. Miller's [7] mentioned that an entrepreneurial firm is the one that is "first to come up with proactive' innovations". McClelland [26] defined pro-activeness as "the ability to take initiative, whenever the situation demands" and referred it as the ability of identifying future trends. Pro-activeness involves creating change, not merely anticipating it Senge, [34], so it is the ability to take initiative by exhibiting goal directed behavior. Cultures that encourage entrepreneurial initiative by supporting entrepreneurial firms to go after opportunities are termed as proactive. Proactive individuals focus on doing what they deem fit to bring to fruition their ideas and pro-active firms take advantage by capitalizing on new opportunities.

\subsection{Competitive Aggressiveness}

Competitive aggressiveness requires resources and the ability from a young venture to sustain an aggressive posture relative to market competitors may be exceedingly difficult when resources are deficient Lumpkin \& Dess [35]. Similarly firms may be engaged in competitively aggressive behavior as a mean to defend their already accumulated resource bases Lumpkin \& Dess [35]. The competitive capabilities are not inherent in an organization, but are rather developed over a period of time as a consequence of its behavior and learning processes Zahra, Nielsen, \& Bogner, [36]. Finally, the complexity and uncertainty of a venture's external environment may require its managers to initially spend time exploring their competitive landscape to determine how venture resources may effectively be employed to support an aggressive strategic posture. The competitive aggressiveness is the culture's acceptance to encourage entrepreneurial firm's to be success oriented, which they achieve by challenging competitors. New ventures must develop intensely competitive spirit and should have an aggressive posture for their survival and success. 


\subsection{Autonomy}

Bower [37] mentioned that the seeds of new ideas often start at lower levels in an organization and this highlights the importance of autonomy to organization members which can be found in an internal corporate venture setting. Two types of autonomy have been identified in literature: autocratic mode and generative mode Davis [38]. In autocratic mode the leader is entrepreneurial and leads the firm accordingly. In contrast, the generative mode refers to entrepreneurial action by members within the firm, in this type the organizational culture of the firm is characterized by entrepreneurial action and this action is carried out by lower level employees. Entrepreneurs and their firms must develop an open culture, which stimulates their independent behavior regardless of societal constraints.

\section{Independent Nature of EO Dimensions}

Lumpkin \& Dess [4] argued that any of the several patterns of behavior can be considered entrepreneurial and recommended that EO construct is multidimensional with individual dimension having a unique and distinct relationship with dependent variable. In sum, the overall conceptualization of EO construct converges with respect to both the independence of dimensions and the key dimensions forming an overall multidimensional firm-level EO construct. Even though there is still no consensus regarding the most suitable attributes of the EO dimensions and its measurement, a multidimensional approach where the dimensions vary independently is slowly becoming part of mainstream research. The underlying rationale is that, if a firm scores high on any one dimension, this doesn't necessarily mean the likelihood of firm exhibiting high score on all other dimensions. Similarly a firm may not exhibit high scores in all dimensions of EO but it may still be considered entrepreneurial. This means that past measurements about the role of EO in affecting firm performance have not been fully representative of the individual contribution of each dimension or has either under-represented the impact of one or more dimensions or over-represented the impact of other dimensions Hughes \& Morgan, [39]. If the dimensions can, and do, vary independently as part of an overall EO construct, then it must be acknowledged that the level of presence and contribution of each dimension can, or does, in fact vary.

Miller [40] while reflecting on the progress made in the field of EO research acknowledged the need to examine the multidimensional nature of EO Construct comprising five dimensions where they may vary independently as sometimes the components or dimensions are more important for understanding entrepreneurial behavior of firms. George \& Marino [41] while examining the dimensional nature of EO construct mentioned that uni-dimensionality may suffer from aggregation effects that a multidimensional view may avoid and uni-dimensional view may not capture how the different dimensions relate to performance outcomes. 


\section{Conclusions}

This article explores the integration of strategy and entrepreneurship streams and focuses on the emergence of Strategic Entrepreneurship/Entrepreneurial Orientation (EO) construct. EO integrates the concept of strategic management and entrepreneurship and the effective combination of various dimensions of EO which make a firm entrepreneurial and leads to competitive advantage. This study strongly favors the inclusion of all five dimensions of EO construct. Hence, the discussion of this study centers toward multidimensional nature of EO construct, where the dimensions act independently. As firms grow, founders must delegate running of the company to professional managers, which may be considered the same as "autonomy" component of the strategic entrepreneurship theory. In the overall analysis, it can be concluded that even though the milestones of firm success outlined above are important by themselves, the outcomes are driven by the entrepreneurial orientation dimensions. The chances of firm level success and growth can be improved by policies that are supportive of innovative firms in their infant stage.

Regardless of the fact that there are many diverse triggers of entrepreneurship, understanding the role of national culture and its influence on entrepreneurial

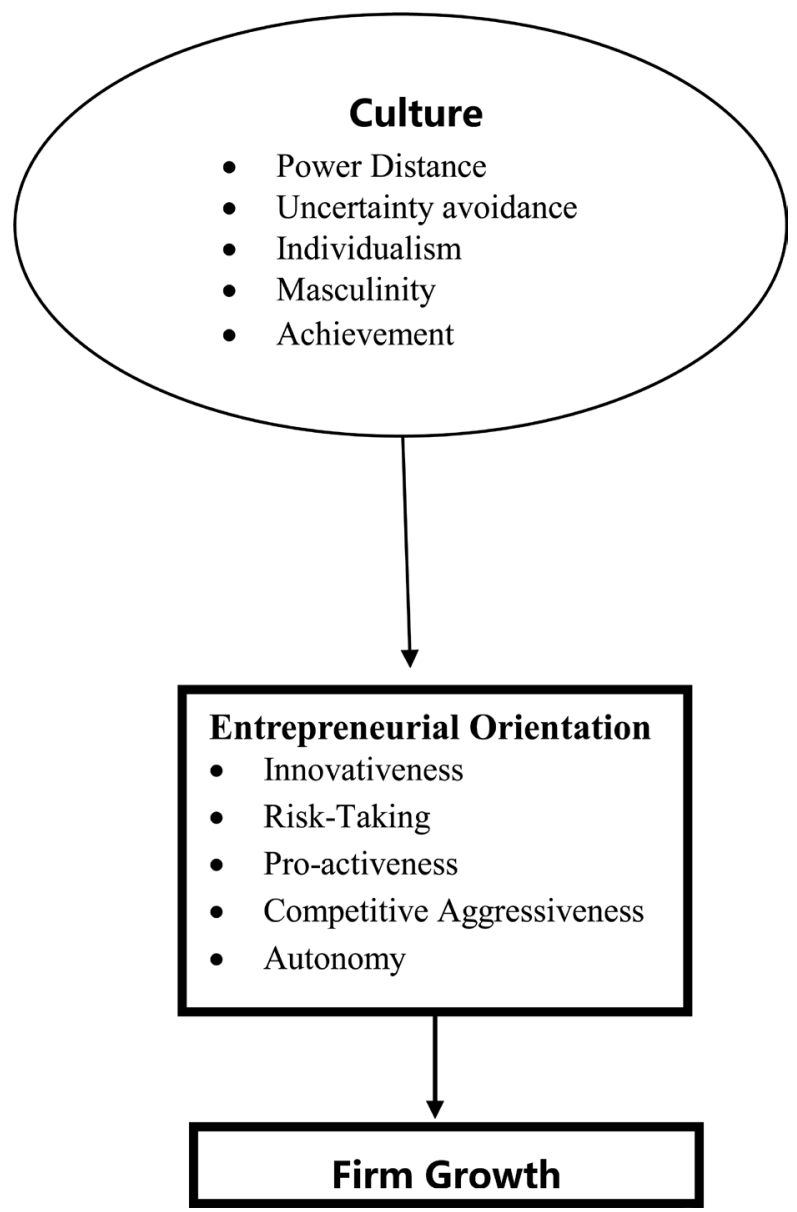

Figure 1. Proposed model. 
activities is important. Hayton et al. [42] underline the relevance and influence of national culture on entrepreneurship which has both practical and theoretical values. The phenomenon of entrepreneurship seems to be more compatible with some cultures than others and in the light of this, the present study proposes the following model (Figure 1).

Studies show most new firms do not survive as independent units beyond their few initial years, and only a handful of them achieve significant growth. Acknowledging the role of culture in the relationship of EO and growth, it is widely believed that cultural background hinders or stimulates entrepreneurial initiatives. This study has suggested a template to study how the national culture and specific aspects of entrepreneurial behavior interact and influence firm. The future studies can build on this template and examine this issue empirically.

\section{References}

[1] Wiklund, J. (1999) The Sustainability of the Entrepreneurial Orientation Performance Relationship. Entrepreneurship Theory \& Practice, 24, 37-48. https://doi.org/10.1177/104225879902400103

[2] Hitt, M.A., Jaeland, M.D., Camp, S.M. and Sexton, D.L. (2001) Strategic Entrepreneurship: Entrepreneurial Strategies for Wealth Creation. Strategic Management Journal, 22, 479-491. https://doi.org/10.1002/smj.196

[3] Berger, B. (1991) The Culture of Entrepreneurship. ICS Press, San Francisco, CA.

[4] Lumpkin, G.T. and Dess, G.G. (1996) Clarifying the Entrepreneurial Orientation Construct and Linking It to Performance. Academy of Management Review, 21, 135-172. https://doi.org/10.5465/amr.1996.9602161568

[5] MacGrath, R. and MacMillan, I. (2000) The Entrepreneurial Mindset. Harvard Business School Press, Boston.

[6] Kuratko, D.F., Ireland, R.D. and Hornsby, J.S. (2001) Improving Firm Performance through Entrepreneurial Actions. Academy of Management Executive, 15, 60-71.

[7] Miller, D. (1983) The Correlates of Entrepreneurship in Three Types of Firms. Management Science, 29, 770-791. https://doi.org/10.1287/mnsc.29.7.770

[8] Covin, J. and Miles, M. (1999) Corporate Entrepreneurship and the Pursuit of Competitive Advantage. Entrepreneurship: Theory \& Practice, 23, 47-63. https://doi.org/10.1177/104225879902300304

[9] Wales, W.J., Gupta, V.K. and Mousa, F.T. (2011) Empirical Research on Entrepreneurial Orientation: An Assessment and Suggestions for Future Research. International Small Business Journal, 31.

[10] Hofstede, G. (1980) Culture's Consequences: International Differences in Work-Related Values. Sage, Beverly Hills, CA.

[11] Trompenaars, F. (1994) Riding the Waves of Culture. Nicholas Brealey, London.

[12] Morris, M.H. (1998) Entrepreneurial Intensity: Sustainable Advantages for Individuals, Organizations, and Societies. Quorum Books, Westport, CT.

[13] Child, J. (1972) Organization Structure, Environment, and Performance: The Role of Strategic Choice. Sociology, 6, 1-22. https://doi.org/10.1177/003803857200600101

[14] Zahra, S.A. (1999) The Changing Rules of Global Competitiveness in the 21st Century. Academy of Management Executive, 13, 36-42.

[15] Burgelman, R.A. (1988) Strategy Making as a Social Learning Process: The Case of 
Internal Corporate Venturing. Interfaces, 18, 74-85.

https://doi.org/10.1287/inte.18.3.74

[16] Schumpeter, J.A. (1936) The Theory of Economic Development. Harvard University Press, Cambridge.

[17] Cooper, A.C. (1971) The Founding of Technologically Based Firms. The Centre for Venture Management, Milwaukee.

[18] Kimberly, J.R. (1981) Managerial Innovation. In: Nystrom, P.C. and Starbuck, W.H., Eds., Handbook of Organizational Design, Oxford University Press, New York, Vol. 1, 84-104.

[19] Miller, D. and Friesen, P. (1982) Innovation in Conservative and Entrepreneurial Firms: Two Models of Strategic Momentum. Strategic Management Journal, 3, 1-25. https://doi.org/10.1002/smj.4250030102

[20] Drucker, P. (1985) The Discipline of Innovation. Harvard Business Review, 63, 67-73.

[21] Knight, G.A. (1997) Firm Orientation and Strategy under Regional Market Integration: A Study of Canadian Firms. International Executive, 39, 351-374. https://doi.org/10.1002/tie.5060390305

[22] Zahra, S.A. and Bogner, W.C. (2000) Technology Strategy and Software New Ventures' Performance: Exploring the Moderating Effect of the Competitive Environment. Journal of Business Venturing, 15, 135-173. https://doi.org/10.1016/S0883-9026(98)00009-3

[23] Zahra, S.A. (1991) Predictors and Financial Outcomes of Corporate Entrepreneurship: An Exploratory Study. Journal of Business Venturing, 6, 259-285. https://doi.org/10.1016/0883-9026(91)90019-A

[24] Cantillon, R. (1734) Essaisur La Nature du Commerce en General. Translation by H. Higgs, MacMillan, London.

[25] Mill, J.S. (1948) Principals of Political Economy with Some of Their Applications to Social Philosophy. J. W Parker, London.

[26] McClelland, D.C. (1965) Achievement Motivation Can Be Developed. Harvard Business Review, 43, 6-25.

[27] Stinchcombe, A. (1965) Social Structure and Organization. In: March, J.G., Ed., Handbook of Organizations, Rand-McNally, Chicago, 142-193.

[28] Covin, J.G. and Slevin, D.P. (1991) A Conceptual Model of Entrepreneurship as Firm Behavior. Entrepreneurship Theory and Practice, 16, 7-24. https://doi.org/10.1177/104225879101600102

[29] Antoncic, B. and Hisrich, R.D. (2003) Corporate Entrepreneurship Contingencies and Organizational Wealth Creation. Journal of Management Development, 23, 518-550. https://doi.org/10.1108/02621710410541114

[30] Penrose, E.T. (1959) The Theory of the Growth of the Firm. Oxford University Press, Oxford.

[31] Lieberman, M. and Montgomery, D. (1988) First Mover Advantages. Strategic Management Journal, 9, 41-58. https://doi.org/10.1002/smj.4250090706

[32] Naman, J.L. and Slevin, D.P. (1993) Entrepreneurship and the Concept of Fit: A Model of Empirical Tests. Strategic Management Journal, 14, 137-153. https://doi.org/10.1002/smj.4250140205

[33] Miller, D. and Camp, B. (1985) Exploring Determinants of Success in Corporate Ventures. Entrepreneurship Theory and Practice, 9, 42-64. 
[34] Senge, P.M. (1992) The Fifth Discipline: The Art and Practice of the Learning Organization. Century Business, London.

[35] Lumpkin, G.T. and Dess, G.G. (2001) Linking Two Dimensions of Entrepreneurial Orientation to Firm Performance: The Moderating Role of Environment and Industry Lifecycle. Journal of Business Venturing, 16, 429-451.

https://doi.org/10.1016/S0883-9026(00)00048-3

[36] Zahra, S.A., Nielsen, A.P. and Bogner, W.C. (1999) Corporate Entrepreneurship, Knowledge, and Competence Development. Entrepreneurship Theory and Practice, 23, 169-189. https://doi.org/10.1177/104225879902300310

[37] Bower, J.L. (1970) Managing the Resource Allocation Process. Harvard University Press, Boston.

[38] Davis, J.L. (2007) Firm Level Entrepreneurship and Performance: An Examination and Extension of Relationships and Measurements of the Entrepreneurial Orientation Construct. Unpublished PhD Thesis from University of Texas, Arlington.

[39] Hughes, M. and Morgan, R. (2007) Deconstructing the Relationship between Entrepreneurial Orientation and Business Performance at the Embryonic Stage of Firm Growth. Journal of Industrial Marketing Management, 36, 651-661. https://doi.org/10.1016/j.indmarman.2006.04.003

[40] Miller, D. (2011) Miller (1983) Revisited: A Reflection on EO Research and Some Suggestions for the Future. Entrepreneurship Theory and Practice, 35, 873-894. https://doi.org/10.1111/j.1540-6520.2011.00457.x

[41] George, B. and Marino, L.D. (2011) The Epistemology of Entrepreneurial Orientation: Conceptual Formation, Modeling and Operationalization. Entrepreneurship Theory and Practice, 35, 989-1024. https://doi.org/10.1111/j.1540-6520.2011.00455.x

[42] Hayton, J.C., George, G. and Zahra, S.A. (2002) National Culture and Entrepreneurship: A Review of Behavioral Research. Entrepreneurship Theory and Practice, 26, 33-52. https://doi.org/10.1177/104225870202600403 